\title{
Study of Heavy Metals in Teas from Romanian Market
}

\author{
GHEORGHE GUTT ${ }^{1 *}$, SONIA AMARIEI ${ }^{1}$, LILIANA NOROCEL ${ }^{2}$ \\ ${ }^{1}$ Faculty of Food Engineering, Stefan cel Mare University, 13 Universitatii Str., 720229, Suceava, Romania \\ ${ }^{2}$ Department of Health and Human Development, Stefan cel Mare University of Suceava, 13 Universitatii Str., 720229, \\ Suceava, Romania \\ The aim of this study was to determine heavy metals levels in some varieties of tea from the Romanian market. \\ For this purpose, 15 samples of tea of the following assortments were analyzed: green tea, black tea, herb tea \\ and fruit tea. Determination of heavy metals traces was achieved with inductively coupled plasma mass \\ spectrometry (ICP-MS). The quantities of $\mathrm{Pb}, \mathrm{Hg}$ and $\mathrm{Cd}$ from analyzed tea samples were compared with the \\ permissible dose in accordance with the Notice of Scientific Panel on Contaminants in the Food Chain of \\ European Food Safety Authority (EFSA).
}

Keywords: tea assortments, heavy metals, principal component analysis

From a chemical point of view, to the category of heavy metals belong nearly 40 metals which produce adverse effects on human health when in contact with food.

Heavy metal toxicity is the result of their binding to enzymes of animal cell systems or to specific components of cellular membranes. Heavy metals are associated, as secondary factors, with complex pathological processes found in humans and animals. Toxic effect occurs above a certain threshold, below which some of them ( $\mathrm{Co}, \mathrm{Cu}, \mathrm{Fe}, \mathrm{Ni}, \mathrm{Zn}, \mathrm{Mn})$ may even be essential elements of compounds involved in various metabolic processes [1]. Thus, if the food were completely devoid of metals, there would occur nutritional deficiencies, as follows: iron is necessary for hemoglobin and its absence causes anemia, calcium and phosphorus are the elements required to build the bone, their absence results in bone deformation and rickets, potassium alkalizes the tissues, sodium plays an important role in chloride secretion, magnesium is an important element for the good functioning of some organs (brain, thymus, adrenal, and so on), with specific role in the body's synthesis process, zinc it is part of tissue synthetization process, manganese, arsenic and other heavy metals have an important role in some other reactions.

Among the heavy metals that contaminate food the following are mentioned: mercury, cadmium, lead, copper, tin, zinc, arsenic. Air, water and soil are considered vehicular pathways through which food can be contaminated [2-7]. Air contamination with heavy metals is achieved due to human activity, such as production of coal, petroleum, non-ferrous metals [8,9]. Steel and iron manufacturing cement production [10-12]. The source of heavy metals contamination in the soil are the fertilizers and pesticides used in agriculture such as fungicides containing mercury, copper, arsenic, zinc $[13,14]$.

Also, another source of soil contamination can be the type of soil and geographical location, it may contain high concentrations of heavy metals or can be deficient in them [15].

Water is an important source of contamination due to spills $[16,17]$, wastewater treatment and pre-treatment activity, discharge of sewage and of household waste $[18,14]$.

Plants absorb from the soil a number of elements, some of which have an unknown biological function and others are known to be toxic at low concentrations. Absorption and bioaccumulation of toxic substances in plants have a negative impact on consumers' health, as are the plants used in the form of teas. Among the absorbed elements, some of them are necessary for plants to complete their life cycle. In addition to these elements, plants also absorb elements that have an unknown biological function and are known to be toxic even at low concentrations [19].

Among them, there are arsenic, cadmium, chromium, mercury, lead. Plants that accumulate more than $100 \mathrm{mg}$ of $\mathrm{Cd} / \mathrm{kg}$ or more than $500 \mathrm{mg}$ of $\mathrm{Cr} / \mathrm{kg}$ in dry leaves are known as hyper accumulators. A review conducted by Garda Torresdey et al., 2005 summarized the study of metals such as $\mathrm{Cd}, \mathrm{Cr}, \mathrm{Cu}, \mathrm{Hg}, \mathrm{Ni}, \mathrm{Pb}, \mathrm{Zn}$ and identified families of hyper accumulator plant species. Some wild plants recently identified as potential hyper accumulators are for example Prosopis sp. [21] and Salsola Kali [22] which were found to be potential $\mathrm{Pb}$ and $\mathrm{Cd}$ accumulators. They are consumed by humans and animals.

An important source of heavy metals is green and black teas, herb teas and fruit teas [23] or a combination of them [19]. It is estimated that today, in the world, tea consumption rises to the astronomical quantity of around one million tones tea per year, or about 500 billion cups of tea per year, in statistical data meaning an average for each inhabitant of

\footnotetext{
*email: g.gutt@fia.usv.ro
} 
about 160 cups. The secret of this extraordinary tea generalization is that the nature has concentrated in the leaves a variety of substances, each of them useful for the body, with subtle flavors and pleasant taste.

The legislation in Romania does not provide maximum limits for heavy metals in tea assortments, but only for total mineral content as in Table 1 .

Table 1

MINERAL LIMITS ALLOWED FOR SOME TEAS ASSORTMENTS IN ROMANIAN PHARMACOPOEIA

\begin{tabular}{|c|c|c|}
\hline No crt. & Teas & Permissible dose of minerals \\
\hline 1. & Goat weed & No more than $0,5 \%$ \\
\hline 2. & Marygold & No more than $0,1 \%$ \\
\hline 3. & Chamomile & No more than $0,25 \%$ \\
\hline 4. & Mint & No more than $1,0 \%$ \\
\hline 5. & Linden & No more than $0,5 \%$ \\
\hline 6. & Valerian & No more than $4,0 \%$ \\
\hline 7. & Yarrow plant & No more than $5 \%$ \\
\hline
\end{tabular}

Knowing the quantities of heavy metals in soft drinks and teas shows a great importance, especially in summer, when the body requires an intense moisturizing. Many plants are components of dietary supplements, so they bring in their composition an amount of heavy metals that will add to that of their essential components [24]. Metal pollutants are usually non degradable and a homeostasis mechanism of discharging them from the human body is not known, so the high level of heavy metals endanger the biological life [9].

In accordance with the Notice of Scientific Panel on Contaminants in the Food Chain of European Food Safety Authority (EFSA), the permissible dose of $\mathrm{Cd}$ is $7 \mu \mathrm{g} / \mathrm{kg}$ body $/$ daily, of $\mathrm{Pb} 25 \mu \mathrm{g} / \mathrm{kg}$ body $/$ daily, and of $\mathrm{Hg}$ is $1,6 \mu \mathrm{g} / \mathrm{kg}$ body/daily.

\section{Experimental part}

\section{Materials and methods}

The research was carried out in order to identify and dose heavy metals in various samples of tea. Samples were purchased from the Romanian market, totalling 15 assortments in the form of bags, from various companies, Table 2.

Table 2

ANALYZED TEA SAMPLES

\begin{tabular}{|c|c|c|}
\hline $\begin{array}{l}\text { Cod of } \\
\text { sample }\end{array}$ & Name sample & Ingredients \\
\hline $\mathrm{C} 1$ & Goat weed & Goat weed (Herba Hyperici) \\
\hline $\mathrm{C} 2$ & Marigold & Marigold flowers (Calendula Officinalis ) \\
\hline $\mathrm{C} 3$ & Jasmine Dream & Soft chinese tea, jasmine \\
\hline $\mathrm{C} 4$ & Chinese green tea & Chinese green tea \\
\hline $\mathrm{C5}$ & Green tea & Mixture of green tea \\
\hline C6 & Black tea & Mixture of black tea \\
\hline $\mathrm{C7}$ & Chamomile & Chamomile flowers (Chamomile) \\
\hline $\mathrm{C} 8$ & Mint & Mint herb( Herba Menthae) \\
\hline C9 & Multivitamin & $\begin{array}{c}\text { Zamos } 40 \% \text {, rosehips } 36 \% \text {,apple } 7 \% \text {, orange peel, } \\
\text { blueberries flavor, blueberries, black currants, } \\
\text { elderberries, vitamin C, niacin, vitamin E, pantothenic } \\
\text { acid, vitamin B1 vitamin B2, folic acid, biotin, vitamin } \\
\text { B12 }\end{array}$ \\
\hline $\mathrm{C} 10$ & Linden tea & Linden flowers (Tiliae ) \\
\hline $\mathrm{C} 11$ & Gentian & Gentian (Asclepiadea) \\
\hline $\mathrm{C} 12$ & Stomach calming tea & $\begin{array}{c}\text { Flowers of acacia (Acaciae), Comfrey root (Symphyti } \\
\text { Radix), Valerian root (Radix Valerianae), Herba } \\
\text { Anserinae, Chamomile flowers, Lemon balm } \\
\text { herb(Herba Melissae) }\end{array}$ \\
\hline $\mathrm{C} 13$ & Rosehip tea & Rosehips $64 \%$, Hibiscus $26 \%$, Aronia $10 \%$ \\
\hline $\mathrm{C} 14$ & Yarrow plant & $\begin{array}{l}\text { Aerial part of the plant Achillea millefolium L., fam. } \\
\text { Asteraceae }\end{array}$ \\
\hline $\mathrm{C} 15$ & Fruit tea & $\begin{array}{c}\text { Zamos, rosehips, apple, orange peel, raspberry flavor } \\
3.5 \% \text {, vanilla flavor } 3 \% \text {, elderberries } 3 \%\end{array}$ \\
\hline
\end{tabular}




\section{Determination of heavy metals}

Determination of heavy metals traces is achieved with mass spectrometry inductively coupled with plasma ICP-MS, Agilent Technologies 7500 Series. Samples preparation is carried out in accordance with SR EN ISO 14082:2003Determination of trace elements by atomic absorption spectrometry after ashing. Dissolving ash obtained from the calcination is performed using high purity reagents $\left(\mathrm{HNO}_{3}\right.$, Merck, Germany, Suprapur grade).

Concentration $(\mathrm{C})$ of heavy metals in samples obtained is expressed in $\mu \mathrm{g} / \mathrm{g}$ sample and is calculated with the formula [26]:

$$
\mathrm{C}=a \cdot \frac{V}{m}
$$

where:

a - concentration value measured by the device, $[\mathrm{ppb}]$;

$\mathrm{V}$ - volume of acid that dissolved the sample [ml];

$\mathrm{m}$ - mass of mineralized sample $[\mathrm{g}]$.

Determination of samples humidity by method of drying in oven.

The sample is dried in an oven under an air stream at atmospheric pressure and at a temperature of $110-130^{\circ} \mathrm{C}$ to a constant weight. Depending on the mass loss is calculated humidity sample, in percent for each sample.

Determination of ash content of tea assortments by means of calcination at $550-600^{\circ} \mathrm{C}$. The ash is the amount of minerals after calcination, non combustible residue that remains from the test sample.

\section{Results and discussions}

Data analysis shows that $\mathrm{C} 11$ samples tea are rich in heavy metals such as $\mathrm{Pb}, \mathrm{Ni}, \mathrm{Cd}, \mathrm{Hg}, \mathrm{Co}$, and in essential elements such as $\mathrm{Zn}$ and $\mathrm{Ag}$ (true antiseptic), which, however, in large amounts can become toxic to the body [27]. Chinese green tea (C4 samples) contains high amounts of As, Bi and U235. C1, C7, C10, C14 tea samples are rich in $\mathrm{Ce}$ and Sn. C2, C5, C6, C13 samples (green tea, black tea, rosehip, calendula) have predominant metals as Al, Cr, Fe, Co, U235 and U238. C9 and C15 tea samples have the lowest amount of heavy metals and minerals.

Results from Table 3 present the characterization of tea assortments according to the content of heavy metals.

Table 3

THE QUANTITIES OF METALS BROUGHT IN THE BODY BY CONSUMPTION OF 1 TEA BAG

\begin{tabular}{|c|c|c|c|c|c|c|c|c|c|c|c|c|c|c|c|}
\hline Sample & $\begin{array}{l}\text { Goat weed } \\
\text { tea [ppb] }\end{array}$ & $\begin{array}{c}\text { Marigold } \\
\text { tea } \\
\text { [ppb] }\end{array}$ & $\begin{array}{c}\text { Jasmine } \\
\text { tea } \\
\text { [ppb] }\end{array}$ & $\begin{array}{c}\text { Chinese } \\
\text { green tea } \\
\text { [ppb] }\end{array}$ & $\begin{array}{c}\text { Green tea } \\
{[\mathrm{pppb}]}\end{array}$ & $\begin{array}{c}\text { Black tes } \\
\text { [ppb] }\end{array}$ & $\begin{array}{c}\text { Chamomile } \\
\text { tea } \\
\text { [ppb] }\end{array}$ & $\begin{array}{c}\text { Mint tea } \\
\text { [ppb] }\end{array}$ & $\begin{array}{c}\text { Multivitamin } \\
\text { tea } \\
{[\mathrm{ppb}]}\end{array}$ & $\begin{array}{c}\text { Linden tea } \\
{[\mathrm{ppp}]}\end{array}$ & $\begin{array}{c}\text { Gentian } \\
\text { tea } \\
\text { [ppb] }\end{array}$ & $\begin{array}{l}\text { Stomach } \\
\text { calming tea } \\
{[\mathrm{ppb}]}\end{array}$ & $\begin{array}{c}\text { Rosehip tea } \\
\text { [ppb] }\end{array}$ & $\begin{array}{c}\text { Yarrow tea } \\
{[\mathrm{ppb}]}\end{array}$ & $\begin{array}{c}\text { Fruit tea } \\
\text { [ppb] }\end{array}$ \\
\hline Element & 0.8123 & 1.5366 & 2.0407 & 2.9952 & 1.7803 & 1.7985 & 0.9847 & 1.6031 & 2.5316 & 1.0622 & 5.0286 & 3.9887 & 4.1942 & 3.1199 & 2.4386 \\
\hline $\mathrm{Li}$ & 3.00936 & 2.11148 & 1.83491 & 1.08323 & 0.74117 & 0.87267 & 1.67005 & 0.91666 & 0.79772 & 0.91273 & 0.01979 & 0.15531 & 0.13578 & 0.35081 & 0.20278 \\
\hline B & 5.30284 & 4.10484 & 1.86578 & 2.18934 & 1.57698 & 1.83903 & 5.89774 & 221914 & 0.91148 & 1.58398 & 0.50859 & 0.50330 & 0.52632 & 1.14026 & 0.51566 \\
\hline $\mathrm{Mg}$ & 84.02068 & 176.20070 & 110.62381 & 115.43470 & 129.61299 & 104.67056 & 186.09729 & 184.48631 & 146.44889 & 221.94502 & 123.44390 & 86.68238 & 112.23833 & 110.82086 & 89.49807 \\
\hline AI & 12.80315 & 14278277 & 38.90822 & 32.35176 & 154.13133 & 92.79956 & 73.01716 & 15.22051 & 8.65066 & 37.09283 & 7.33803 & 23.66686 & 939392 & 10.22469 & 9.90322 \\
\hline $\mathrm{K}$ & & 0 & 0 & 0 & 0 & 0 & 0 & 0 & 0 & 0 & 0 & 0 & 0 & 0 & 0 \\
\hline $\mathrm{C}_{\mathrm{a}}$ & 115.72079 & 313.35416 & 162.44426 & 169.10390 & 214.28973 & 184.32027 & 260.48543 & 518.68255 & 367.94912 & 665.12898 & 423.87543 & 208.46391 & 305.54099 & 306.58034 & 166.69400 \\
\hline $\mathrm{Cr}$ & & 0.25055 & 0.02083 & 0.17027 & 0.16009 & 0.21407 & 0.12694 & 0.10916 & 0.09283 & 0.09179 & 0.04176 & 0.06518 & 0.06795 & 0.03045 & 0.07176 \\
\hline $\mathrm{Mn}$ & 8.84525 & 5.65209 & 66.12192 & 72.59448 & 119.32539 & 95.87712 & 8.05829 & 11.18770 & 13.79957 & 9.11787 & 9.93020 & 5.74999 & 10.71360 & 4.62675 & 8.07225 \\
\hline $\mathrm{Fe}$ & 9.91013 & 140.76533 & 15.33787 & 58.86084 & 63.92181 & 21.57353 & 97.79628 & 19.52467 & 9.40117 & 45.94238 & 20.14477 & 33.54476 & 17.59573 & 9.23103 & 7.70934 \\
\hline$c_{0}$ & 0.01634 & 0.08999 & 0.02856 & 0.04032 & 0.04818 & 0.03379 & 0.05410 & 0.02855 & 0.03092 & 0.04309 & 0.04937 & 0.02715 & 0.02582 & 0.01948 & 0.01672 \\
\hline$N_{1}$ & 0.19389 & 0.26357 & 0.30872 & 0.43570 & 0.66281 & 0.51710 & 0.30974 & 0.14347 & 0.16985 & 0.17887 & 1.23394 & 0.19555 & 0.12636 & 0.12981 & -0.00718 \\
\hline $\mathrm{Cu}$ & 1.52345 & 1.52122 & 2.40726 & 1.13932 & 1.34107 & 1.48040 & 1.51061 & 0.97467 & 0.73570 & 1,35332 & 0.57919 & 0.53589 & 0.42618 & 0.46877 & 0.16915 \\
\hline$Z_{n}$ & 2.61603 & 2.68450 & 3.73646 & 2.62921 & 2.31703 & 1.87656 & 2.10724 & 241719 & 1.92566 & 2.70665 & 7.87993 & 2.97316 & 1.28153 & 1.72281 & 0.56385 \\
\hline $\mathrm{Ga}$ & 0.08002 & 0.14805 & 0.03430 & 0.02754 & 0.05055 & 0.03058 & 0.16249 & 0.15127 & 0.05530 & 0.13180 & 0.09794 & 0.11094 & 0.17107 & 0.10177 & 0.01640 \\
\hline A. & 0.02431 & 0.06329 & 0.43845 & 0.17353 & 0.13748 & 0.04712 & 0.07337 & 0.05287 & 0.02656 & 0.11744 & 0.04867 & 0.04506 & 0.04107 & 0.02957 & 0.01938 \\
\hline Se & 0.01293 & 0.00960 & 0.00821 & 0.00810 & 0.01643 & 0.01070 & 0.01523 & 0.01669 & 0.00859 & 0.06990 & 0.00482 & 0.01047 & 0.00697 & 0.01418 & 0.00267 \\
\hline Br & 0.15388 & 0.91110 & 0.53903 & 0.53419 & 0.39319 & 0.48652 & 0.81243 & 0.99807 & 0.56289 & 0.58840 & 0.12429 & 1.69228 & 0.53646 & 7.37203 & 0.16403 \\
\hline$A g$ & & & & & & & & & & & 3380.6626 & & & & \\
\hline$c d$ & 1988.18171 & 449.04334 & 142.10810 & 272.10203 & 176.93647 & 62.55213 & 1335.43211 & 383.63171 & 134.30242 & 202.4100 & 2921.2902 & 348.48447 & 92.98555 & 253.21324 & 35.88124 \\
\hline Sn & & 276.5846 & 833.04748 & 475.76122 & 533.61793 & 417.01418 & & & 108.62696 & 14309.9228 & 109.37438 & 200.56660 & 131.13343 & 8.01308 & 41.00714 \\
\hline $\mathrm{Ce}$ & 2634.49464 & & 8141.814 & 13309.628 & 15371.0048 & 7848.206 & 32867.878 & 8025.076 & 6661.79491 & 17524.948 & 7430.4975 & 11248.0256 & 9504.79233 & 2921.56800 & 3942.83605 \\
\hline $\mathrm{Pt}_{\mathrm{t}}$ & 0 & 0.0000049 & & 0.000009 & & & & & 0.000006 & 0 & 0 & 0.000001 & 0 & 0 & \\
\hline $\mathrm{Au}$ & 0 & 0.0000166 & 0.0000013 & 0.000004 & 0.00000044 & 0.0000016 & 0.000023 & 0.000012 & 0.000029 & 0.000474 & 0.000004 & 0.000003 & 0 & 0.0000004 & 0.0000094 \\
\hline $\mathrm{Hg}$ & - & & & & & & & & & & 0.000363 & & & & \\
\hline $\mathrm{pb}$ & & 0.024405 & 0.037977 & 0.032552 & 0.037915 & & 0.040622 & 0.021833 & & 0.042365 & 0.104403 & 0.050142 & 0.03338 & 0.027244 & \\
\hline $\mathrm{Bi}$ & 0.000388 & 0.001425 & 0.001269 & 0.006540 & 0.003842 & 0.000954 & 0.000802 & 0.000524 & 0.000302 & 0.000249 & 0.000316 & 0.000286 & 0.00046 & $0.00015 ?$ & 0.000170 \\
\hline U & & 0.002912 & 0.000723 & 0.001411 & 0.001109 & 0.000320 & 0.001752 & 0.001232 & 0.000109 & 0.001389 & 0.000393 & 0.001375 & 0.00131 & 0.000112 & 0.000431 \\
\hline $\mathrm{U}$ & 0.000369322 & 0.002554 & 0.000858 & 0.001394 & 0.001503 & 0.000639 & 0.002970 & 0.001201 & 0.000504 & 0.001671 & 0.000532 & 0.001485 & 0.00129 & 0.000313 & 0.000605 \\
\hline
\end{tabular}

Principal Component Analysis was performed with the software Unscrambler X 10.1 according to the humidity content, ash and mineral concentrations in different samples of tea. This analysis identifies the assortments of teas chemically similar. Principal component analysis was performed to assess the overall effect of chemical composition on the origin of teas.

In Figure 1 and Figure 2 are presented the sample scores in reduced space and the influence of chemical composition of the principal component analysis. Component 1 (PC1) explained $81 \%$ of the variation, while component 2 (PC2) explained $17 \%$ of the variation, total percentage variation of the two principal components being of $98 \%$. 


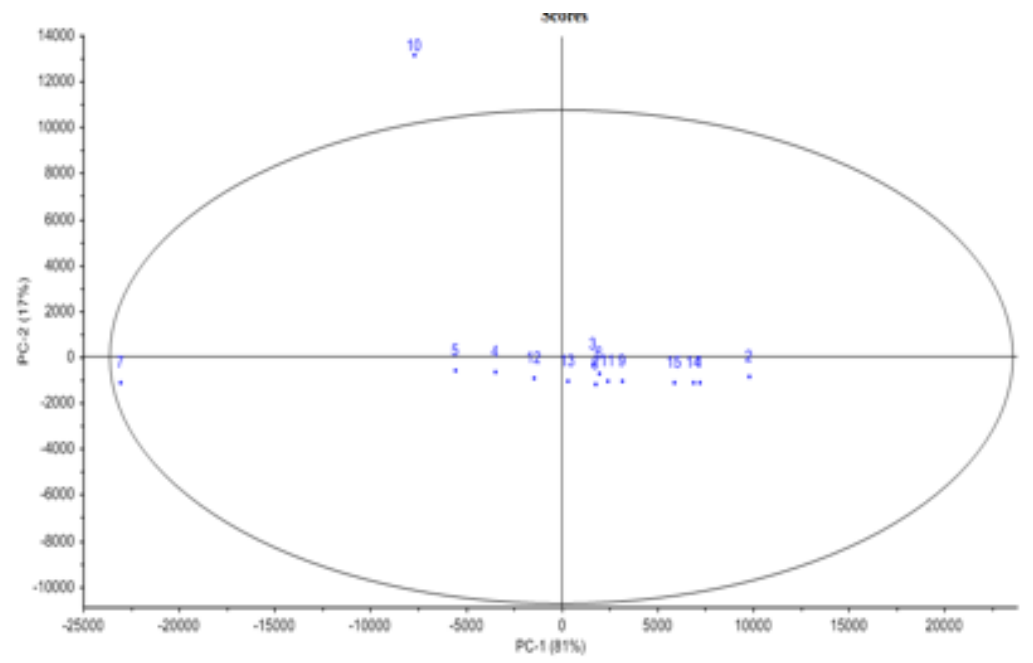

Fig. 1. The influence of chemical composition of the principal component analysis

In Figure 1 there is an agglomeration of types of tea in one group, only two types of tea are not grouped with the others, the two types are Chamomile tea (C7) and linden tea (10) due to the much higher concentration of $\mathrm{Mg}$ in the two teas against the other teas examined. The location of linden tea at the top of PC1 is due to the concentration of Sn.

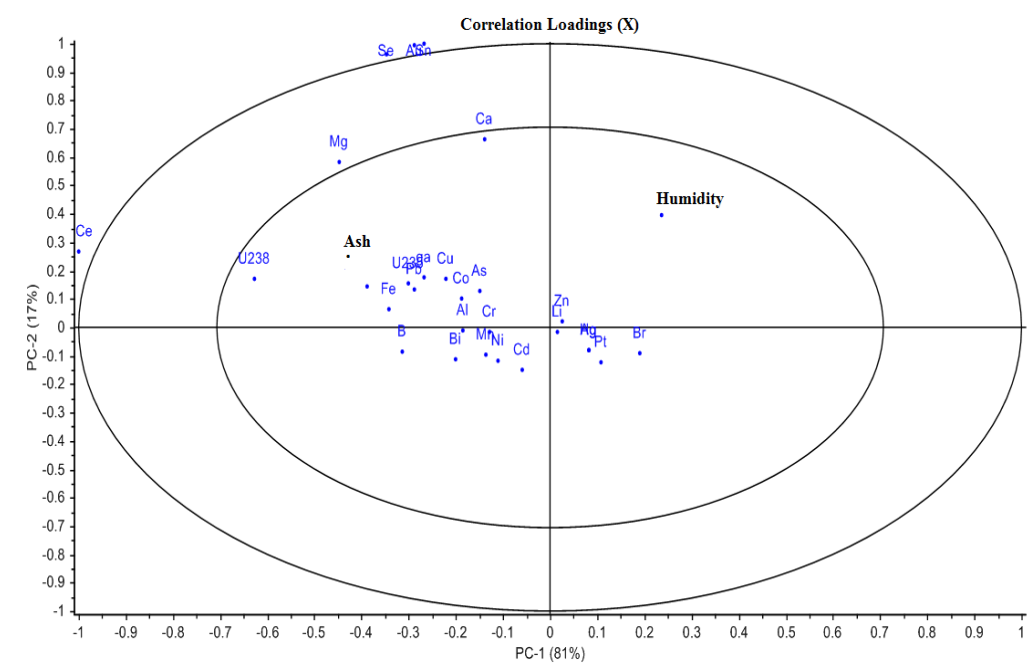

Fig. 2. Distribution of chemical compounds in tea

Both $\mathrm{Mg}$ and $\mathrm{Sn}$ are the parameters that significantly influence the variation (their distribution in Figure 2 shows them at a greater distance from origin located on the left side; the parameters on the left side of the component PC2 have a greater influence than those located to the right side of the component). Figure 2 shows that $\mathrm{Zn}, \mathrm{Li}, \mathrm{Cd}$ and $\mathrm{Ag}$ concentrations are situated close to the origin of the coordinates, indicating that these parameters are not useful in the total variance. PC1 distinguishes the samples according to the content of $\mathrm{Ce}$ and $\mathrm{U} 238$, while PC2 distinguishes samples according to the content of Se, Au and Sn.

\section{Conclusions}

Teas are considered to be small chemical laboratories because the plants which are so useful for their effects on the body in some situations, concentrate essentially thousands of substances still unknown.

After grouping the various teas, the analysis showed that $\mathrm{C} 11$ tea samples are the richest in metals such as $\mathrm{Pb}, \mathrm{Ni}$, $\mathrm{Cd}, \mathrm{Hg}$, Co. The quantities of $\mathrm{Pb}$ and $\mathrm{Hg}$ from analyzed samples do not represent a threat to health, even if consumed in the desired amount, because in accordance with the European Food Safety Authority (EFSA) the permissible dose is $25 \mu \mathrm{g} \mathrm{Pb} / \mathrm{kg}$ body/daily respectively $1.6 \mu \mathrm{g} \mathrm{Hg} / \mathrm{kg}$ body/daily.

Regarding the cadmium content, some samples have a higher quantity than the permissible dose such as: 2.72 times for Chamomile tea (C7), 4.05 times for Goat Weed tea (C1) and of 5.96 times for Gentian tea (C11) even for a single tea bag. For others tea assortments the consumption can be 2-10 tea bags without exceeding the permissible dose of $7 \mu \mathrm{g}$ $\mathrm{Cd} / \mathrm{kg} /$ daily (considered for an average body weight of $70 \mathrm{~kg}$ ).

From the analyzed data of tea samples and taking into consideration the permissible doses for heavy metals according to EFSA, except the three teas with a high content in Cd: Goat Weed (C1), Chamomile (C7) and Gentian (C11), the other teas can be appreciated without health risk even if consumed in the desired amount. 


\section{References}

1.YANG CHUN, LIU YUAN, DU JUN, TANG BIN (2012), SVM. Physics Procedia 33, 212-215.

2. MOHAMED H.H. ALI, KHAIRIA M. AL-QAHTANI (2012), Egyptian Journal of Aquatic Research 38, 31-37.

3. LORETTA GRATANI, MARIA FIORE CRESCENTE, LAURA VARONE (2008), Atmospheric Environment 42, 8273-8277.

4. A. KASASSI, P. RAKIMBEI, A. KARAGIANNIDIS, A. ZABANIOTOU, K. TSIOUVARAS, A. NASTIS, K. TZAFEIROPOULOU (2008), Bioresource Technology 99, 8578-8584.

5. SHAN WU, XINGHUI XIA, CHUNYE LIN, XI CHEN, CHUANHUI ZHOU (2010), Journal of Hazardous Materials 179, 860-868.

6. SUZHEN CAO, XIAOLI DUAN, XIUGE ZHAO, JIN MA, TING DONG, NAN HUANG, CHENGYE SUN, BIN HE, FUSHENG WEI (2014), Science of the Total Environment 472, 1001-1009.

7. CRISTINA DINU, ELEONORA MIHAELA UNGUREAN, GABRIELA GEANINA VASILE, LIDIA KIM, LUOANA FLORENTINA PASCU, MARIUS SIMION, Rev. Chim., 69, no. 11, p. 3241

8. LIAO GUO-LI, LIAO DA-XUE, LI QUAN-MING (2008), Trans. Nonferrous Met. Soc. China 18, 207-211.

9. WU YAO-GUO, XU YOU-NING, ZHANG JIANG-HUA, HU SI-HAI (2010), Transaction of Nonferrous Metals Society of China 20, 688694.

10. HUANG YIZONG, HU YING, LIU YUNXIA (2009), Acta Ecologica Sinica 29, 320-326.

11. Q.X. ZHOU, Z.M. GAO (1994), Elsevier, Agro-environmental Protection 13, 148-151.

12. SUN HONG-FEI, LI YONG-HUA, JI YAN-FANG, YANG LIN-SHENG, WANG WU-YI, LI HAI-RONG (2010), Trans.Nonferrous Met.Soc.China 20, 308-314.

13. BIN FANG, XUEQIN ZHU (2014), Food Control 39, 62-67.

14.TSANANGURAYI TONGESAYI, PATRICK FEDICK, LAUREN LECHNER, CHRISTIANA BROCK, ARIELLE LE BEAU, CHELSEA BRAY (2013), Food and Chemical Toxicology 62, 142-147.

15. BINGGAN WEI, LINSHENG YANG (2010), Microchemical Journal 94, 99-107.

16. NOOR-UL-AMIN, ANWAR HUSSAIN, SIDRA ALAMZEB, SHUMAILA BEGUM (2013), Food Chemistry 136, $1515-1523$.

17. IONESCU P., DEAK, G., DIACU E., RADU V.M., 2016) Rev. Chim. 67, no. 11, 2148

18. N. SRIDHARA CHARYA, C.T. KAMALA, D. SAMUEL SUMAN RAJB (2008), Ecotoxicology and Environmental Safety 69, 513-524.

19. XIN LI, ZHAOWEI ZHANG, PEIWU LI, QI ZHANG, WEN ZHANG, XIAOXIA DING, (2013),. Food Research International 53, 649-658. 20. GARDEA-TORRESDEY JL, DE LA ROSA G, PERALTA-VIDEA JR, MONTES M, CRUZ-JIMENEZ G, CANO-AGUILERA I. (2005), Arch Environ Contam Toxicol, 48:225-32.

21. ALDRICH MV, GARDEA-TORRESDEY JL, PERALTA-VIDEA JR, PARSONS JG. (2003), Environ Sci Technol; 37:1859-64.

22. DE LA ROSA G, PERALTA-VIDEA JR, MONTES M, PARSONS JG, GARDEA-TORRESDEY JL.(2004), Chemosphere; 55:1159-68.

23. BECCALONI ELEONORA, FABIANA VANNI, MASSIMILIANO BECCALONI, MARIO CARERE, (2013), Microchemical Journal 107, $190-195$.

24. H. TUMIR, J. BOŠNIR, I. VEDRINA-DRAGOJEVIC', Z. DRAGUN D, S. TOMIC', D. PUNTARIC', G. JURAK (2010), Food Control 21, 885-889.

25.*** SR EN ISO 14082:2003-Determination of trace elements by atomic absorption spectrometry.

26. AMARIEI, S., GUTT, G., \& OROIAN, M. (2017), Rev. Chim, 68, no. 6, 1298

27. NA ZHENG, JINGSHUANG LIU, QICHAO WANG, ZHONGZHU LIANG (2010), Science of the Total Environment 408, 726-733.

Manuscript received: 14.12 .2018 
Rev. Chim. $\downarrow 11$ no. $2 \downarrow 2020 \downarrow$ https://revistadechimie.ro 166 
Rev. Chim. $\downarrow 1 \downarrow$ no. $2 \downarrow 2020 \downarrow$ https://revistadechimie.ro 167 


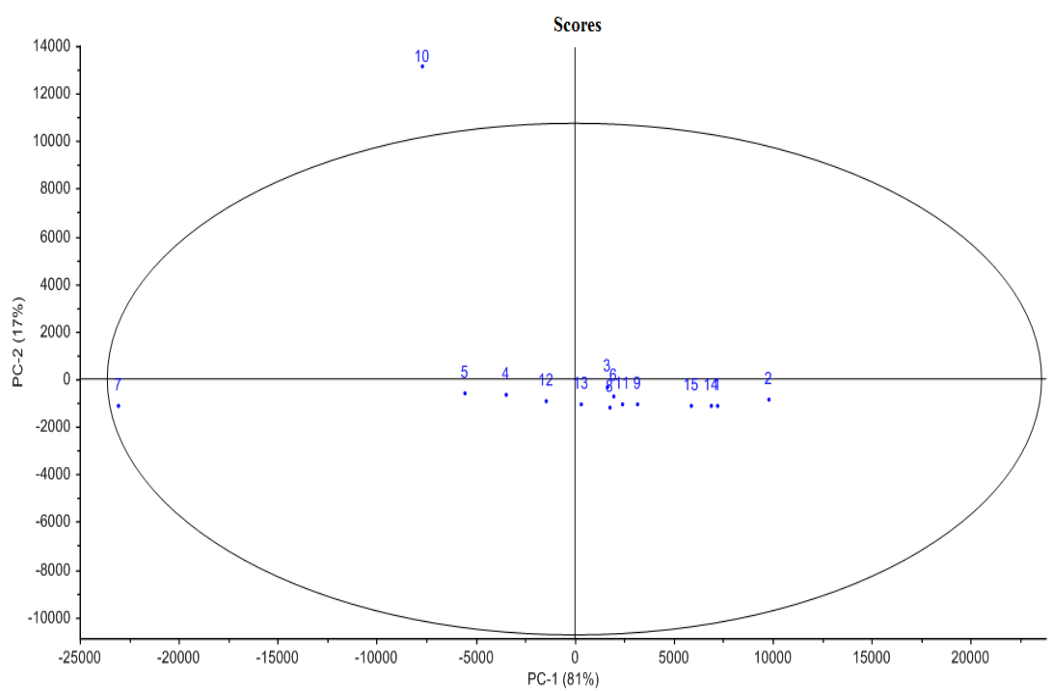

Fig. 1. The influence of chemical composition of the principal component analysis

In Figure 1 there is an agglomeration of types of tea in one group, only two types of tea are not grouped with the others, the two types are Chamomile tea (C7) and linden tea (10) due to the much higher concentration of Mg in the two teas against the other teas examined. The location of linden tea at the top of PC1 is due to the concentration of Sn.

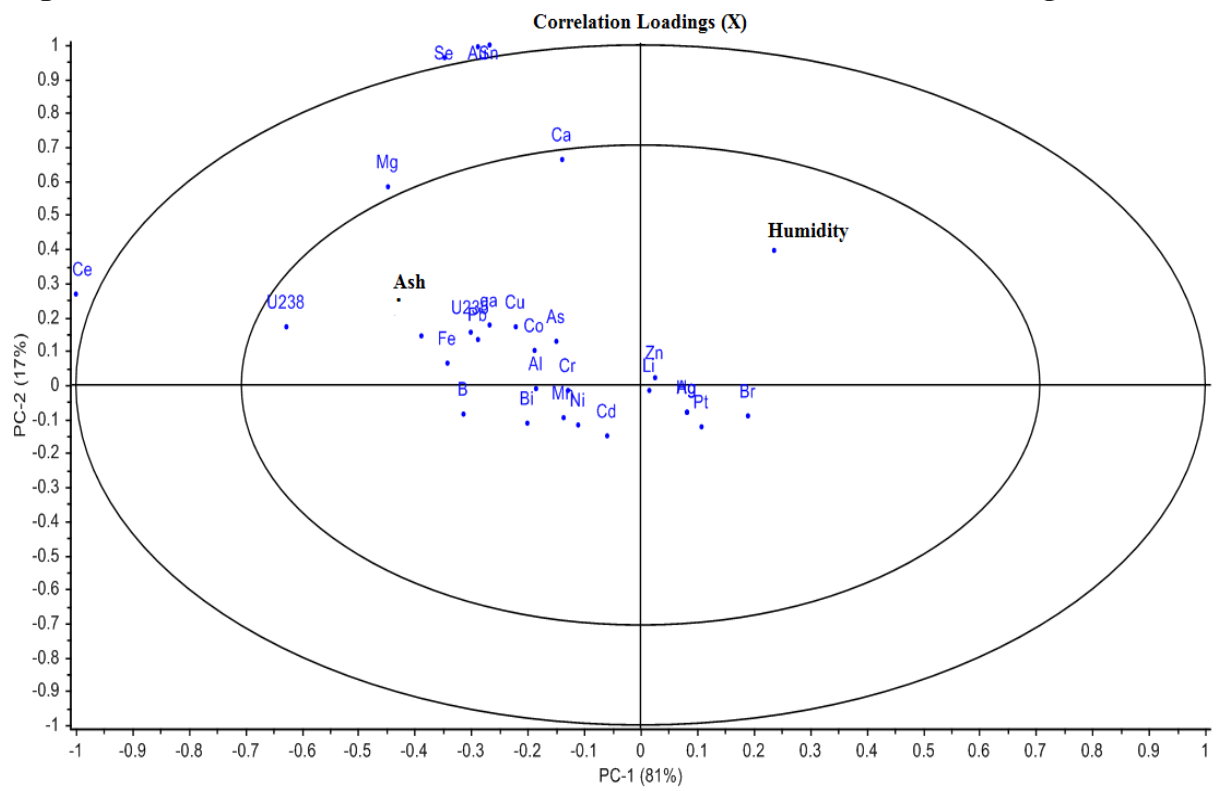

Fig. 2. Distribution of chemical compounds in tea

Both Mg and Sn are the parameters that significantly influence the variation (their distribution in Figure 2 shows them at a greater distance from origin located on the left side; the parameters on the left side of the component PC2 have a greater influence than those located to the right side of the component). Figure 2 shows that $\mathrm{Zn}, \mathrm{Li}, \mathrm{Cd}$ and $\mathrm{Ag}$ concentrations are situated close to the origin of the coordinates, indicating that these parameters are not useful in the total variance. PC1 distinguishes the samples according to the content of $\mathrm{Ce}$ and $\mathrm{U} 238$, while PC2 distinguishes samples according to the content of Se, Au and Sn.

\section{Conclusions}

Teas are considered to be small chemical laboratories because the plants which are so useful for their effects on the body in some situations, concentrate essentially thousands of substances still unknown.

After grouping the various teas, the analysis showed that $\mathrm{C} 11$ tea samples are the richest in metals such as $\mathrm{Pb}, \mathrm{Ni}$, $\mathrm{Cd}, \mathrm{Hg}$, Co. The quantities of $\mathrm{Pb}$ and $\mathrm{Hg}$ from analyzed samples do not represent a threat to health, even if consumed in the desired amount, because in accordance with the European Food Safety Authority (EFSA) the permissible dose is $25 \mu \mathrm{g} \mathrm{Pb} / \mathrm{kg}$ body/daily respectively $1.6 \mu \mathrm{g} \mathrm{Hg} / \mathrm{kg}$ body/daily.

Regarding the cadmium content, some samples have a higher quantity than the permissible dose such as: 2.72 times for Chamomile tea (C7), 4.05 times for Goat Weed tea (C1) and of 5.96 times for Gentian tea (C11) even for a single tea bag. For others tea assortments the consumption can be 2-10 tea bags without exceeding the permissible dose of $7 \mu \mathrm{g}$ $\mathrm{Cd} / \mathrm{kg} /$ daily (considered for an average body weight of $70 \mathrm{~kg}$ ). 
From the analyzed data of tea samples and taking into consideration the permissible doses for heavy metals according to EFSA, except the three teas with a high content in Cd: Goat Weed (C1), Chamomile (C7) and Gentian (C11), the other teas can be appreciated without health risk even if consumed in the desired amount.

\section{References}

[1] Yang Chun, Liu Yuan, Du Jun, Tang Bin (2012), SVM. Physics Procedia 33, 212-215.

[2] Mohamed H.H. Ali, Khairia M. Al-Qahtani (2012), Egyptian Journal of Aquatic Research 38, 31-37.

[3] Loretta Gratani, Maria Fiore Crescente, Laura Varone (2008), Atmospheric Environment 42, 8273-8277.

[4] A. Kasassi, P. Rakimbei, A. Karagiannidis, A. Zabaniotou ,K. Tsiouvaras, A. Nastis, K. Tzafeiropoulou (2008), Bioresource Technology 99, 8578-8584. 868.

[5] Shan Wu, Xinghui Xia, Chunye Lin, Xi Chen, Chuanhui Zhou (2010), Journal of Hazardous Materials 179, 860-

[6] Suzhen Cao, Xiaoli Duan, Xiuge Zhao, Jin Ma, Ting Dong, Nan Huang, Chengye Sun, Bin He, Fusheng Wei (2014), Science of the Total Environment 472, 1001-1009.

[7] Cristina Dinu, Eleonora Mihaela Ungurean, Gabriela Geanina Vasile, Lidia Kim, Luoana Florentina Pascu, Marius Simion, (2018) Rev. ch. 69, (11) 3241-3247.

[8] Liao Guo-Li, Liao Da-Xue, Li Quan-Ming (2008), Trans. Nonferrous Met. Soc. China 18, 207-211.

[9] Wu Yao-guo, Xu You-ning, Zhang Jiang-hua, Hu Si-hai (2010), Transaction of Nonferrous Metals Society of China 20, 688-694.

[10] Huang Yizong, Hu Ying, Liu Yunxia (2009), Acta Ecologica Sinica 29, 320-326.

[11] Q.X. Zhou, Z.M. Gao (1994), Elsevier, Agro-environmental Protection 13, 148-151.

[12] Sun Hong-fei, Li Yong-hua, Ji Yan-fang, Yang Lin-sheng, Wang Wu-yi, Li Hai-rong (2010), Trans.Nonferrous Met.Soc.China 20, 308-314.

[13] Bin Fang, Xueqin Zhu (2014), Food Control 39, 62-67.

[14] Tsanangurayi Tongesayi, Patrick Fedick, Lauren Lechner, Christiana Brock, Arielle Le Beau, Chelsea Bray (2013), Food and Chemical Toxicology 62, 142-147.

[15] Binggan Wei, Linsheng Yang (2010), Microchemical Journal 94, 99-107.

[16] Noor-ul-Amin, Anwar Hussain, Sidra Alamzeb, Shumaila Begum (2013), Food Chemistry 136, 1515-1523.

[17] Ionescu P., Deak, G., DIACU E., RADU V.M., 2016) Rev. chim. 67 (11), 2148-2150.

[18] N. Sridhara Charya, C.T. Kamala, D. Samuel Suman Rajb (2008), Ecotoxicology and Environmental Safety 69, $513-524$.

[19] Xin Li, Zhaowei Zhang, Peiwu Li, Qi Zhang, Wen Zhang, Xiaoxia Ding, (2013),. Food Research International 53, 649-658.

[20] Gardea-Torresdey JL, de la Rosa G, Peralta-Videa JR, Montes M, Cruz-Jimenez G, Cano-Aguilera I. (2005), Arch Environ Contam Toxicol, 48:225-32.

[21] Aldrich MV, Gardea-Torresdey JL, Peralta-Videa JR, Parsons JG. (2003), Environ Sci Technol; 37:1859-64. 68.

[22] De la Rosa G, Peralta-Videa JR, Montes M, Parsons JG, Gardea-Torresdey JL.(2004), Chemosphere; 55:1159-

[23] Beccaloni Eleonora, Fabiana Vanni, Massimiliano Beccaloni, Mario Carere, (2013), Microchemical Journal 107, 190-195.

[24] H. Tumir, J. Bošnir, I. Vedrina-Dragojevic', Z. Dragun d, S. Tomic', D. Puntaric', G. Jurak (2010), Food Control 21, 885-889.

[25] SR EN ISO 14082:2003-Determination of trace elements by atomic absorption spectrometry.

[26] Amariei, S., Gutt, G., \& Oroian, M. (2017), Rev. Chim, 68(6), 1298-1301.

[27] Na Zheng, Jingshuang Liu, Qichao Wang, Zhongzhu Liang (2010), Science of the Total Environment 408, 726 733. 
